DOI

\title{
EXPERIMENTAL MODELING OF PROCESS OF WATER SOLUTIONS EVAPORATION IN THE VACUUM AND MICROWAVE FIELD CONDITIONS
}

Burdo O. ${ }^{1}$, ScD, professor, Mordynskiy V. ${ }^{1}$, PhD, associate professor, Gavrilov A. ${ }^{2}$, PhD, associate professor, Sirotyuk I. ${ }^{1}$, postgraduate student, Sereda A. ${ }^{1}$, engineer

${ }^{1}$ Odessa National Academy of Food Technologies, Odessa, Ukraine

${ }^{2}$ Academy of bioresources and nature management «Vladimir Vernadskiy CFU», Crimea, Ukraine

\begin{abstract}
A comparative analysis of traditional methods for the food solutions concentration is given. The main problem of classical evaporators is identified, which is associated with the impossibility of obtaining high concentrations of the finished product due to a sharp increase in its viscosity and temperature through the formation of a boundary layer. A scientific and technical hypothesis has been formulated, representing a possible solution to this problem by providing a volume supply of energy directly to the moisture of the product. Thermophysical scheme of evaporation processes by traditional and innovative methods is considered. Their fundamental differences are highlighted and the relevance of the development of an innovative evaporation method is substantiated. The scheme of the innovative evaporator is presented, which allows to obtain the finished product in the solid phase with a final concentration of up to $90^{\circ} \mathrm{brix}$. By the example of apple juice, experiments were conducted to study the effect of pressure of the electromagnetic field on the steam output of the apparatus. Dependencies that indicate a constant evaporation rate throughout the entire process, up to a concentration of 80-85 ${ }^{\circ} \mathrm{brix}$, were built. The product temperature did not exceed $35-40{ }^{\circ} \mathrm{C}$, which may indicate its high nutritional value. The above data confirm the formulated hypothesis about the possibility of transition in the process of evaporation from the boundary conditions of the $3 r d$ type to the boundary conditions of the 2nd type by the using microwave energy. On the basis of the obtained results, a model in the criterial form was obtained, which makes it possible to accurately calculate the performance of a microwave vacuum evaporator in certain ranges of the number of energetic action and the obtained dimensionless complex.
\end{abstract}

Key words: evaporation, vacuum, microwave field, boundary conditions, modeling.

\section{ЕКСПЕРИМЕНТАЛЬНЕ МОДЕЛЮВАННЯ ПРОЦЕСУ ВИПАРЮВАННЯ ВОДНИХ РОЗЧИНІВ В УМОВАХ ВАКУУМУ ТА МІКРОХВИЛЬОВОГО ПОЛЯ}

Бурдо О.Г. ${ }^{1}$, д.т.н., професор, Мординський В.П. ${ }^{,}$, к.т.н., доцент, Гаврилов О.В. ${ }^{2}$, к.т.н., доцент, Сиротюк I.B. ${ }^{1}$, аспірант, Середа O.O. ${ }^{1}$, інженер

1 Одеська національна академія харчових технологій, Одеса, Україна

${ }^{2}$ Академія біоресурсів та природокористування «КФУ ім. В.І. Вернадського», АР Крим, Украӥна

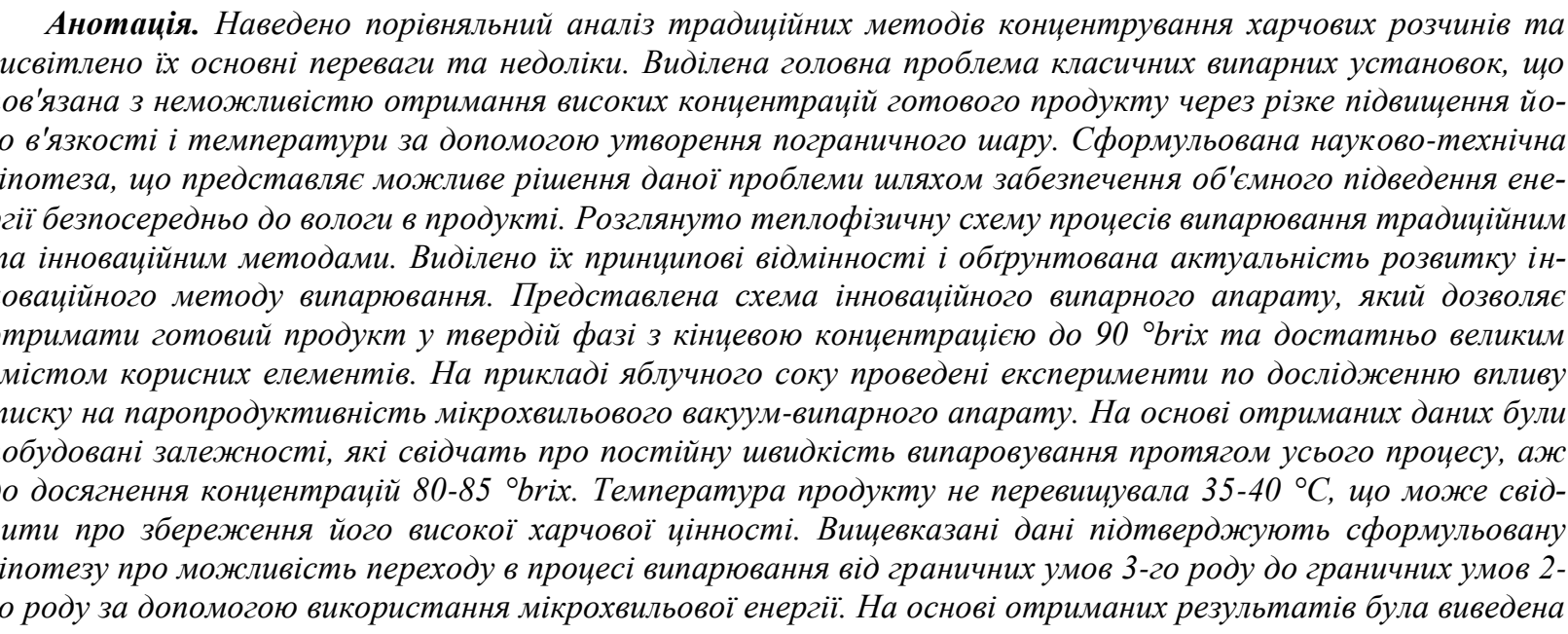


модель в критеріальній формі, щзо дозволяє з високою точністю розрахувати продуктивність мікрохвильового вакуум-випарного апарату в певних діапазонах числа енергетичної дї̈ і отриманого безрозмірного комплексу.

Ключові слова: випаровування, вакуум, мікрохвильове поле, граничні умови, моделювання.

1. Introduction. The modern stage of human development is characterized by 3 fundamental problems: energy, ecology, food. These problems are indicated in the global predictive model of the Club of Rome [1,2]. The problem of food is determined by the concept of functional nutrition [3, 4]. An important task in this concept is the safety of products [5], their high quality. Among the promising products a special place is given to juices [6]. The dynamic increase in the cost of energy determines the interest in food concentrates. Concentrates of food solutions attract manufacturers by the fact that they require lower costs during storage and transportation; have a longer shelf life [7]. However, the process of dehydration solutions is energy-intensive. In addition, the dehydration process should not reduce the nutritional value of the concentrate. The solution to the complex of these problems is relevant and requires serious scientific research [8].

2. Problem analysis and formulation of the scientific and technical hypothesis. In the dehydration technique, three principles of moisture removal are used: membrane, evaporation and cryoconcentration. Membrane technologies are becoming more common in the problems of desalination and wastewater treatment [9]. Membrane technologies are not widely used for the concentration of juices and extracts. Evaporation technologies have the greatest use for the concentration of food solutions [10]. This is explained by the fact that the devices for evaporation are extremely simple, provide high performance [10]. However, the quality requirements of the concentrate are constantly increasing. At the same time, the main problem of evaporators is that with an increase in the concentration of the solution, its viscosity increases, the intensity of the solution circulation in the apparatus decreases, the thermal resistance of the boundary layer and its temperature increase. No successful solutions to this problem were found. In practice, there are limited to the final concentration value of the finished product (from 25 to $60 \%$ ).

The high quality of the finished product is provided by cryoconcentration technologies [11], especially block freezing [12]. At the same time, despite the energy characteristics and guarantees of high quality of the finished product, cryoconcentration technologies are limited to final concentrations up to $50{ }^{\circ}$ brix. Therefore, the task was posed to: develop a technology for the concentration of food solutions, which, with high energy efficiency and preservation of the product nutritional value, would provide higher values of final concentrations than traditional technologies.

The solution of the problem is based on the hypothesis: "the use of the innovative scheme of energy supply to the food solution when changing the traditional scheme with $\mathrm{BC}$ of the 3rd type with $\mathrm{BC}$ of the 2rd type will allow a volumetric supply of energy to the polar molecules, which will ensure almost complete removal of moisture from the solution".

Such principles successfully solve problems of drying [13- 15].

3. Innovative evaporation technology modeling.

$2)$.

Consider the fundamental differences between innovative, proposed ideas from traditional evaporators. (Fig. 1,

\begin{tabular}{|c|c|c|c|c|c|c|}
\hline $\begin{array}{l}\text { The solution } \\
\text { and heating } \\
\text { stream sup- } \\
\text { ply to the } \\
\text { apparatus }\end{array}$ & $\begin{array}{l}\text { Heat emission } \\
\text { during steam } \\
\text { condensation } \\
\text { on the evapo- } \\
\text { rator wall }\end{array}$ & $\begin{array}{l}\text { Thermal } \\
\text { conduc- } \\
\text { tivity } \\
\text { through } \\
\text { the wall }\end{array}$ & $\begin{array}{l}\text { Boundary } \\
\text { layer for- } \\
\text { mation on } \\
\text { the inner } \\
\text { wall }\end{array}$ & $\begin{array}{l}\text { Increasing of the } \\
\text { solution concen- } \\
\text { tration and growth } \\
\text { of the thermal } \\
\text { resistance of layer }\end{array}$ & $\begin{array}{l}\text { Heat transfer } \\
\text { intensity re- } \\
\text { ducing, the } \\
\text { layer tempera- } \\
\text { ture increasing }\end{array}$ & $\begin{array}{c}\text { Steam } \\
\text { produc- } \\
\text { tivity } \\
\text { reducing }\end{array}$ \\
\hline
\end{tabular}

Fig. 1 - Thermophysical model of traditional technology of evaporation processes

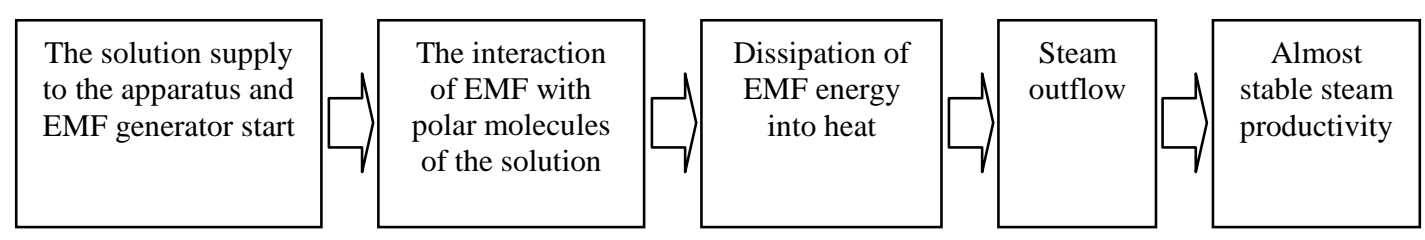

Fig. 2 - Thermophysical model of innovative technology of evaporation processes

The proposed evaporation technology is fundamentally different from traditional solutions in that the "path" of energy to water molecules is much simpler. (Fig. 2).

Thus, innovative technology is fundamentally different from the traditional:

1. The energy supply to the solution at the BC of the 3rd type is changed by the volumetric energy supply at the $\mathrm{BC}$ of the 2 nd type. 
Одеська начіональна академія харчових технологій МОДЕЛЮВАННЯ ЕНЕРГОТЕХНОЛОГІЙ. ОПТИМІЗАЦІЯ ОБЛАДНАННЯ ТА СИСТЕМ

2. The address energy supply directly to the water molecules will allow: to organize a stable steam productivity up to $5-10 \%$ moisture content in a solution with a simple process control scheme.

The mathematical justification of the idea is considered by the authors in the publication [16]. The task is to prove these hypotheses experimentally, to investigate the kinetics and energetics of innovative evaporation.

\section{Discussion of experimental modeling results.}

The specific tasks of experimental studies are formulated on the basis of the parametric model analysis.

The quality parameters are steam productivity and specific energy consumption for concentration of $1 \mathrm{~kg}$ of product. Input parameters, in general, are the thermophysical properties of the solution, its consumption, initial and final values of the solution concentration and temperature. The sets of parameters that characterize the design of the device are taken into account: height, diameter and product volume. Important parameters are the nergy criteria of electromagnetic generators: power and efficiency.

Complex experimental studies were conducted on the stand, described in [16].

The experiment tasks were:

1. Determine the effect of EMF power, pressure, concentration of the solution, its type, chamber loading level on the steam outflow kinetics.

2. Set the dependence of the steam generation rate on the input parameters.

3. Analyze the database of experimental data and present them as a model in generalized variables.

The research objects were water homogeneous and heterogeneous systems (Table 1).

Table 1

Experimental modeling range

\begin{tabular}{|c|c|c|c|c|c|c|}
\hline \multirow{2}{*}{ Object } & \multirow{2}{*}{ Solvent } & \multirow{2}{*}{$\begin{array}{c}\text { Pressure, } \\
\mathrm{MPa}\end{array}$} & \multirow{2}{*}{ Temperature, ${ }^{\circ} \mathrm{C}$} & \multirow{2}{*}{ Power, W } & \multicolumn{2}{|c|}{ Concentration, $\%$} \\
\hline & & & & & Initial & Final \\
\hline Apple juice & Water & $0,01-0,02$ & $35-60$ & $200-900$ & 11,6 & 45,8 \\
\hline Echinacea juice & Water & 0,01 & $35-40$ & 200 & 13,5 & 36,3 \\
\hline Beet juice & Water & 0,01 & $35-40$ & 200 & 12,2 & 81,3 \\
\hline Milk & Water & 0,01 & $35-40$ & 200 & 12 & 29 \\
\hline Tomato paste & Water & 0,01 & $35-40$ & 200 & 16 & 54,8 \\
\hline Oak & Water & 0,01 & $35-40$ & 200 & 63 & 82,6 \\
\hline Sand & Water & 0,01 & $35-40$ & 200 & 74,1 & 97,8 \\
\hline
\end{tabular}

At the first stage of research, partial dependences of the input parameters influence on the amount of moisture removed from the solution, the kinetics of the solution concentration growth, the process thermograms and the values of the vaporization rate (Fig. 3-5) were built. The experiment results on the apple juice concentration are discussed below.

Pressure effect. The experiments were conducted at low pressures (Fig. 3) that is of practical interest for most juices and extracts.

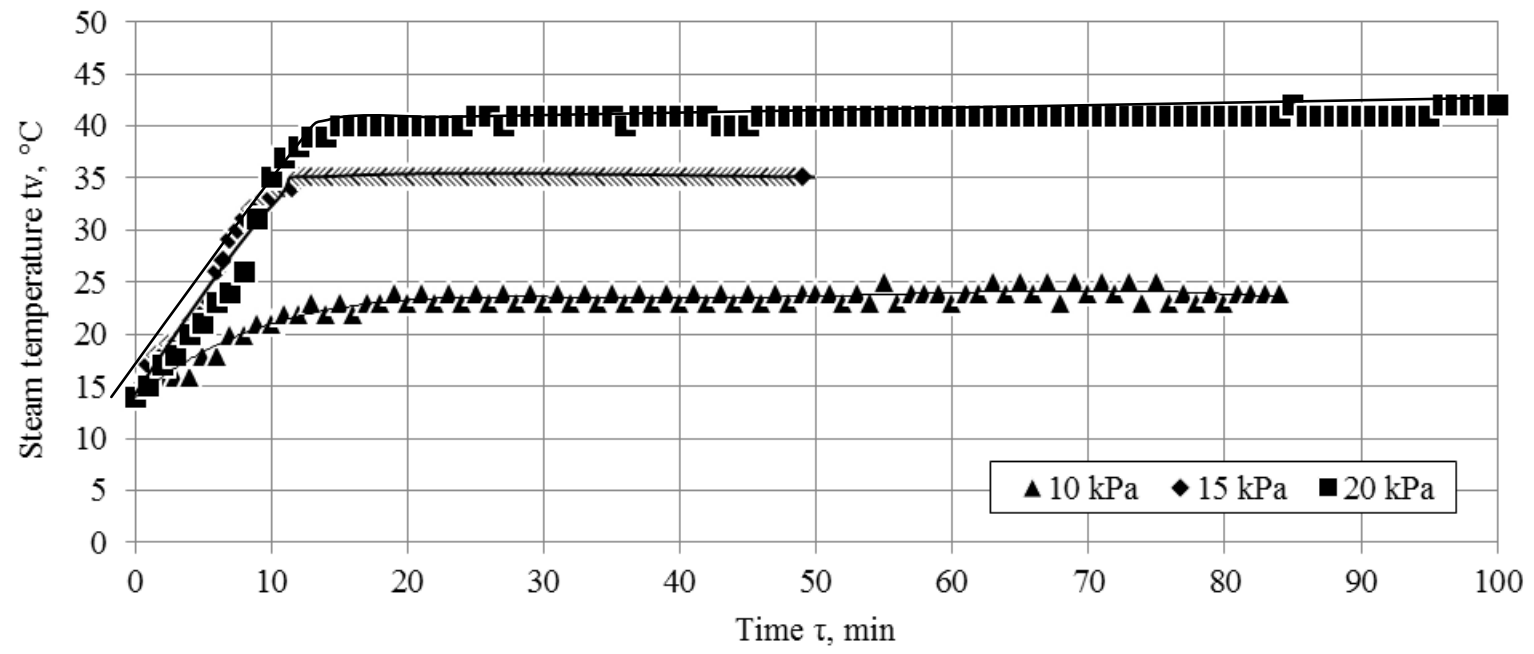

Fig. 3 - The pressure effect on the temperature of the apple juice evaporation process

Наукові праці, Том 83, випуск 1

Scientific Works, Volume 83, Issue 1 
Одеська наиіональна академія харчових технологій МОДЕЛЮВАННЯ ЕНЕРГОТЕХНОЛОГІЙ. ОПТИМІЗАЦІЯ ОБЛАДНАННЯ ТА СИСТЕМ

The results of the experiments (Fig. 3) allow to make three conclusions:

- the systems of energy supply to the solution and removing energy during condensation of the reheat steam function in a coordinated manner - the evaporation temperature remains stable.

- the installation design meets all requirements for tightness, there is no leakage from the environment.

- the temperature levels of the evaporation process meet the technological regulations for the production of high quality concentrate.

The next step in the research was to establish the pressure effect on the kinetics of the increase in solution concentration (Fig. 4).

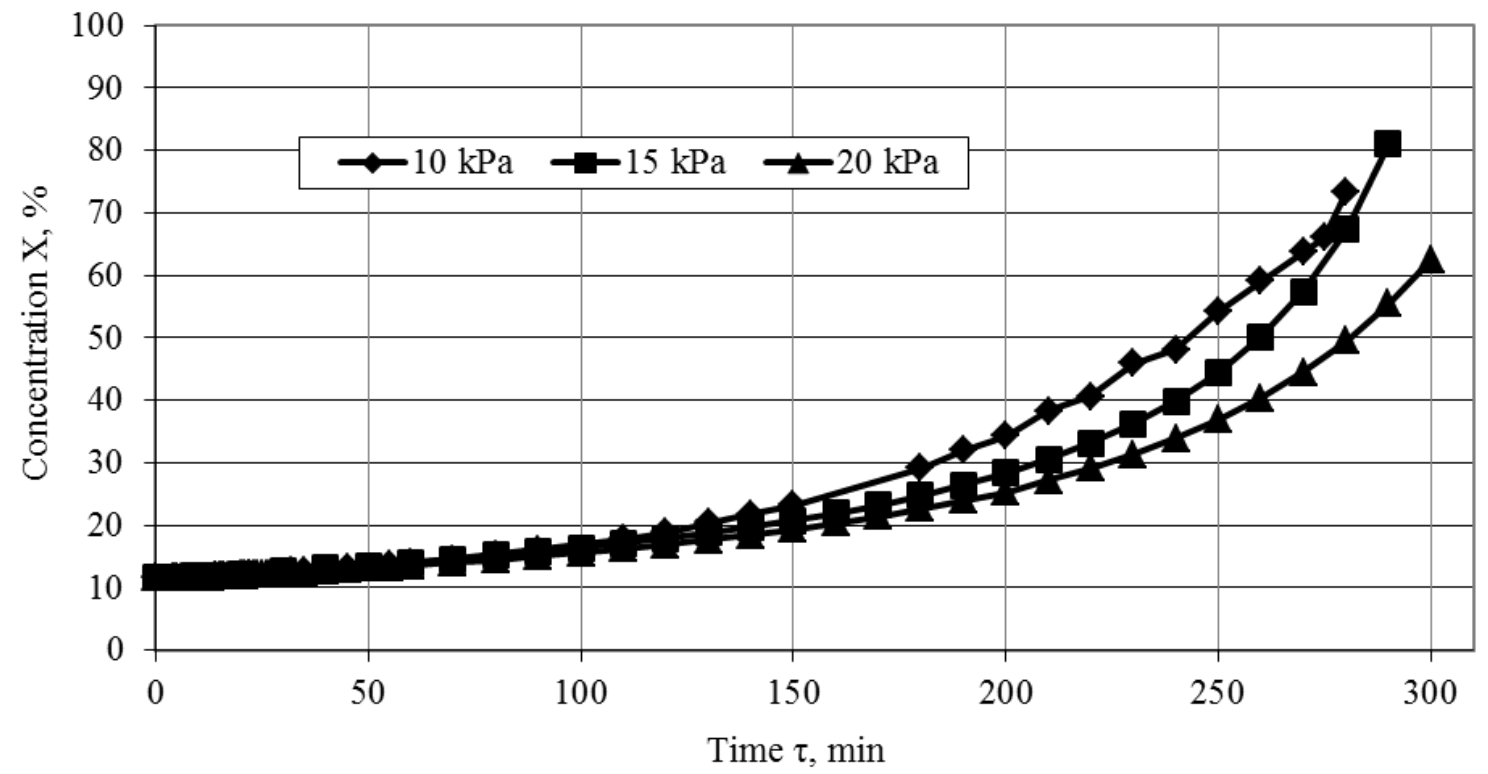

Fig. 4 - The pressure effect on the kinetics of changes in the apple juice concentration

It is seen (Fig. 4) that at a pressure of $10 \mathrm{kPa}$, the intensity of the increase in the juice concentration is higher. The difference in juice concentrations at a pressure in range of $10 \mathrm{kPa}$ to $20 \mathrm{kPa}$ reaches $15-20 \%$.

The determining factor in the evaporation process is the steam productivity (W). The obtained values of the condensate weight were information for determining the steam productivity and evaporation speed (Fig. 5). The dependence is plotted across the entire range of obtained concentrations.

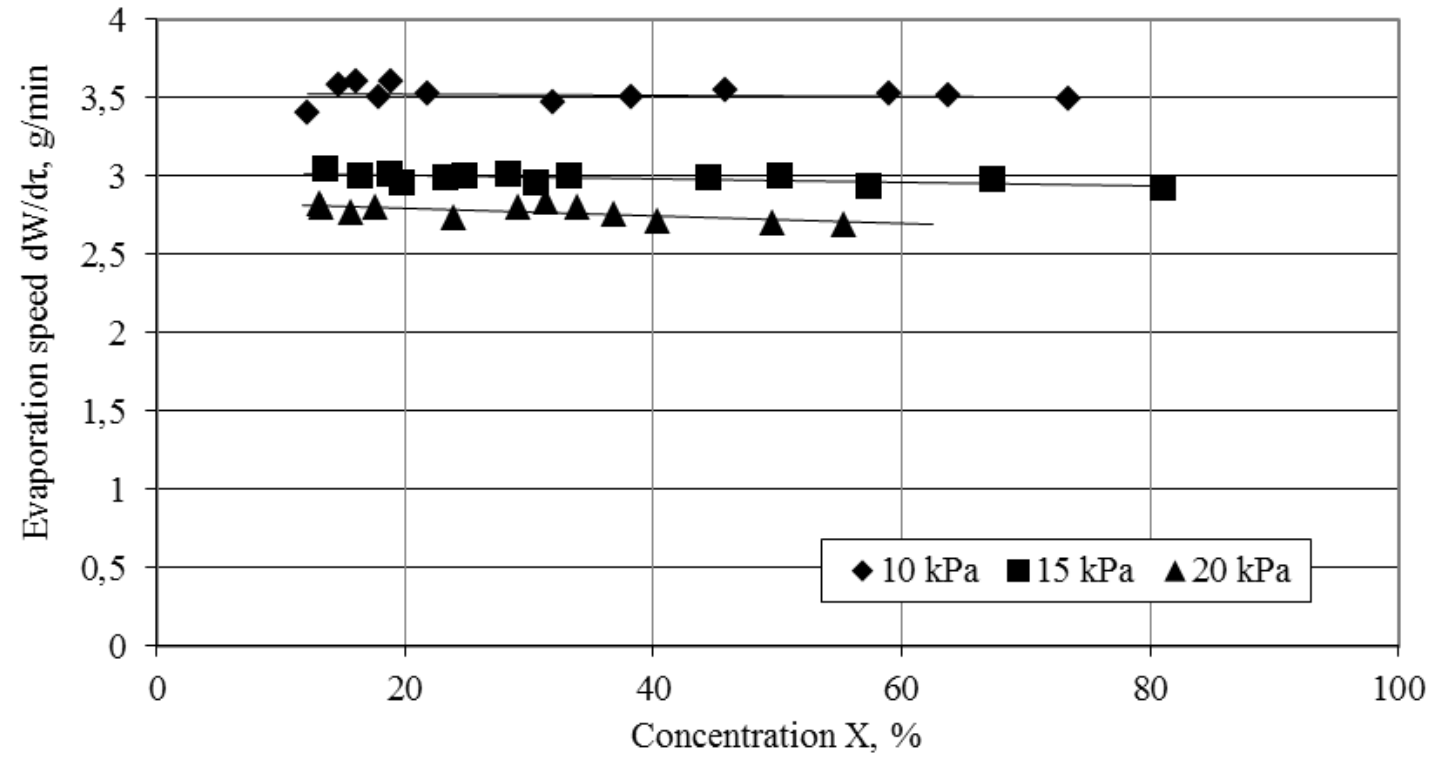

Fig. 5 - The pressure effect on the apple juice evaporation speed 
Одеська начіональна академія харчових технологій МОДЕЛЮВАННЯ ЕНЕРГОТЕХНОЛОГІЙ. ОПТИМІЗАЦІЯ ОБЛАДНАННЯ ТА СИСТЕМ

The decrease in pressure in the chamber leads to an increase in the evaporation speed. In the studied range, this value reaches $20 \%$.

General conclusions on the pressure effect are as follows:

- reducing the pressure in the evaporation chamber has a positive effect on all the characteristics of the process: it lowers the temperature, increases the intensity of steam productivity, shortens the time and increases the value of the final concentration.

- the investigated pressure range closes practical conditions of the developed apparatus.

The second factor that significantly determines the effectiveness of evaporation and makes it possible to control the process is the power of the electromagnetic field.

Experimental data for all products are summarized and the model is obtained in the criteria form. The dependence of the dimensionless steam productivity $(\mathrm{W})$ on the number of energy action $(\mathrm{Bu})$ and the group of parametric dimensionless complexes $(\Omega, \mathrm{P})$ is determined. These numbers of similarity and complexes have the form.

$$
B u=\frac{N_{c}}{W_{c} \cdot r_{c}} ; \Omega=\frac{N_{c}}{N_{b}} ; P=\frac{P_{c}}{P_{b}}
$$

where, $W_{c}, N_{c}, P_{c}$ - current values of plant efficiency, power and pressure respectively;

$N_{b}, P_{b}$ - basic values of power $(200 \mathrm{~W})$ and pressure $(0,01 \mathrm{MPa})$ respectively.

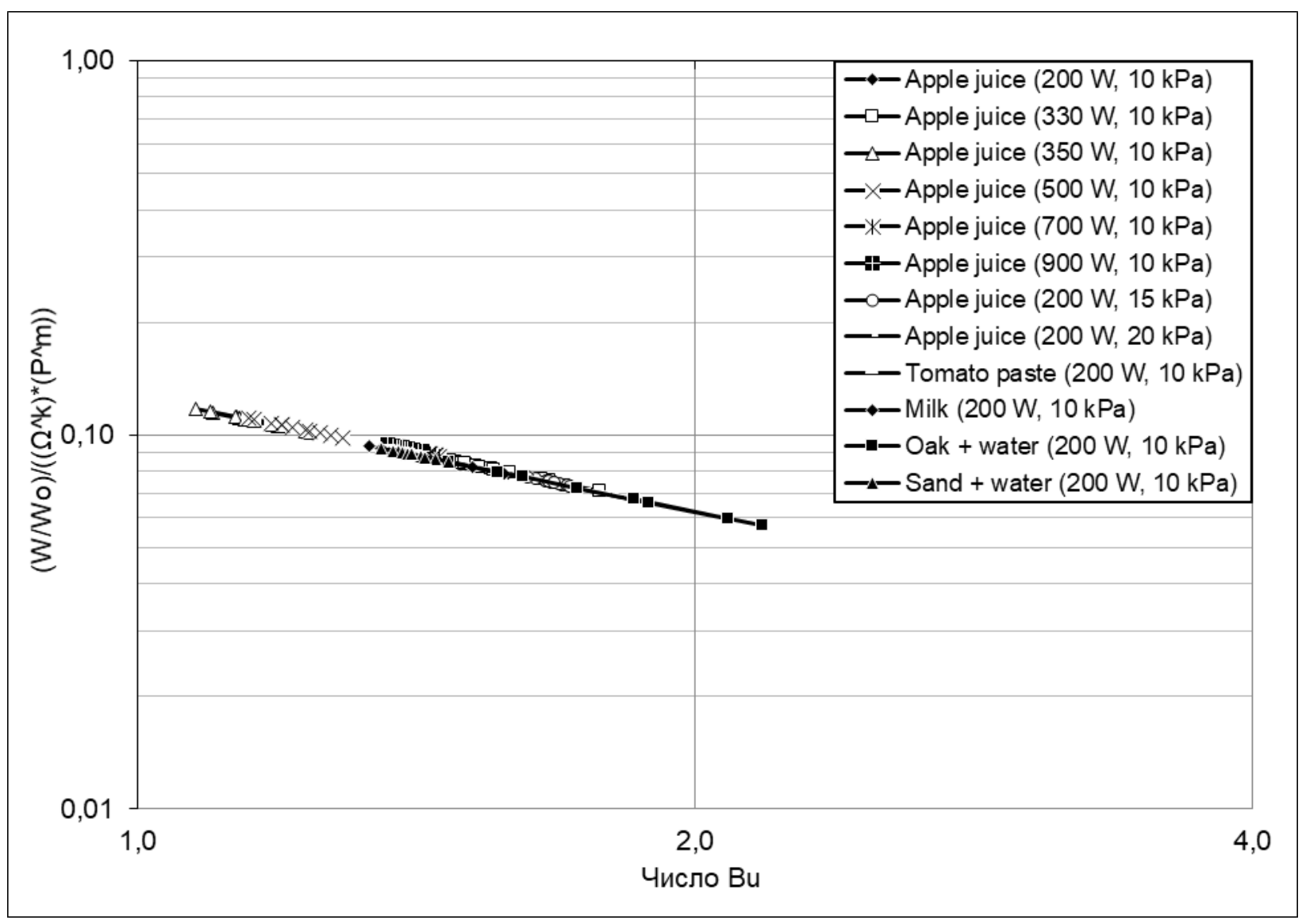

Fig. 6 - Generalization of the experimental database

The sought criterial model is:

$$
W=\frac{W_{c}}{W_{b}}=0,575 \cdot B u^{-1} \cdot \Omega^{0,98} \cdot P^{-0,58}
$$


where, $W_{b}$ - basic value of plant efficiency $(1 \mathrm{~g} / \mathrm{sec})$.

The equation (2) is recommended for calculating the steam productivity of a microwave vacuum evaporator for concentrating water-containing food structures in a wide range of concentrations, up to $85^{0}$ brix.

\section{Conclusions.}

The hypothesis about the possibility of organizing the evaporation process without traditional heat transfer has been proved. The transition from the $\mathrm{BC}$ of the $3 \mathrm{rd}$ type to the $\mathrm{BC}$ of the 2 nd type with the gradient-free supply of electromagnetic energy provides conditions for obtaining high-quality concentrate. The possibility of obtaining concentrates with $90^{\circ}$ brix (almost solid phase) in an evaporator is shown.

\section{References.}

1. Gabor, D., Colombo, U., King, A. S. (2016). Beyond the age of waste: a report to the Club of Rome. Elsevier. 258 p.

2. Clapp, J., Newel,1 P., Brent, Z. W. (2018). The global political economy of climate change, agriculture and food systems. The Journal of Peasant Studies, 45(1), 80-88.

3. Gürlek, C., Yarkent, Ç., Köse, A. Oral, İ.,Öncel, S.Ş., Elibol, M. (2019). Evaluation of several microalgal extracts as bioactive metabolites as potential pharmaceutical compounds. IFMBE Proceedings, 73, 267-272.

4. Prosekov, A. Y., Ivanova, S. A. (2018). Food security: The challenge of the present. Geoforum, 91, 73-77.

5. Figiel, A., Michalska, A. (2017). Overall quality of fruits and vegetables products affected by the drying processes with the assistance of vacuum-microwaves. International Journal of Molecular Sciences, 18(1), paper №71.

6. Adnan, A., Mushtaq, M., \& Islam, T. ul. (2017). Fruit Juice Concentrates. Fruit Juices: Extraction, Composition, Quality and Analysis. 217-240. https://doi.org/10.1016/B978-0-12-802230-6.00012-6.

7. Dincer, C., Tontul, I., Topuz, A. (2016). A comparative study of black mulberry juice concentrates by thermal evaporation and osmotic distillation as influenced by storage. Innovative Food Science and Emerging Technologies, 38(1), 57-64.

8. Yang, X.-B., Zhao, L., Goh, K., Sui, X.-L., Meng, L.-H., Wang, Z.-B. (2019). A phosphotungstic acid coupled silica-Nafion composite membrane with significantly enhanced ion selectivity for vanadium redox flow battery. Journal of Energy Chemistry, 41, 177-184.

9. Simić, S., Orašanin, G., Golubović, D., Milić, D., Batinić, K. (2019). Consideration of Opportunities for the Optimization of Heat Energy Consumption in Industry and Energetics. Lecture Notes in Networks and Systems, 76, 494-503.

10. Khajehei, F., Niakousari, M., Eskandari, M. H., Sarshar, M. (2015). Production of pomegranate juice concentrate by complete block cryoconcentration process. Journal of Food Process Engineering, 38(5), 488-498.

11. Trishin, F.A., Trach, A.R., Orlovskaya, Yu.V. (2018). Upravlenie potokami enerhii v nizkotemperaturnykh razdelitel nykh ustanovkakh. Probleme energeticii regionale, 1(36), 72-86.

12. Kumar, C., Karim, M. A. (2019). Microwave-convective drying of food materials: A critical review. Critical reviews in food science and nutrition, 59(3), 379-394.

13. Monteiro, Ricardo L., et al. (2018). Microwave vacuum drying and multi-flash drying of pumpkin slices. Journal of food engineering, 232, 1-10.

14. Burdo, O., Bandura, V., Zykov, A., Zozulyak, I., Levtrinskaya, Y., Marenchenko, E. Development of wave technologies to intensify heat and mass transfer processes. Eastern-European Journal of Enterprise Technologies, 4(11), 34-42.

15. Burdo, O.G., Syrotyuk, I.V., Alhury, U., Levtrinska, J.O. (2018). Microwave Energy, as an Intensification Factor in the Heat-Mass Transfer and the Polydisperse Extract Formation. Problemele energeticii regionale, 1(36), 58-71.

16. Burdo, O.G., Burdo, A.K., Davar, Rostami Pour, Sirotyuk I.V.(2017). Technologies of selective energy supply during food solutions evaporation. Problemele energeticii regionale, 1(33), 100-109.

Отримано в редакцію 08.04.2019

Прийнято до друку 22.06.2019
Received 08.04.2019

Approved 22.06.2019 